\title{
Analisis Pengendalian Kualitas pada Proses Produksi Crankshaft dengan Menggunakan Metode DMAIC di PT XYZ
}

\author{
Murwan widyantoro $^{1 *}$, Denielson Adisyah $^{2}$ \\ Teknik Industri Fakultas Teknik, Universitas Bhayangkara Jakarta \\ e-mail: ${ }^{* 1}$ murwan@dsn.ubharajaya.ac.id, ${ }^{2}$ deniolsonadisyah20@ gmail.com \\ *Korespondensi: murwan@dsn.ubharajaya.ac.id
}

\begin{abstract}
PT. XYZ is a company in the machining and engineering industry. The specialization of PT. XYZ is in manufacturing press parts, dies, jigs, machinery and construction. one of its products is the crank shaft. there are a number of defects that exceed the company's tolerance standards. During the period March to August, 1,139 pieces of defect were found. Six sigma is a method used for quality control, which aims to eliminate product defects and reduce costs. There are five types of defects found, namely broken, scratched, oversized, loose, and worn. With the Pareto diagram it is known that there are four types of the most dominant crankshaft defects, namely: beret $29.41 \%$, broken $26.42 \%$ worn $16.06 \%$, and loose $14.31 \%$. By using the fishbone diagram, it can be concluded that the main factor of the defect is that the blade part used in the machine is not up to standard, machine maintenance is not maximal, lack of air ventilation, and low quality of raw materials.
\end{abstract}

Keywords : Defect Crankshaft, Six Sigma, DMAIC

\begin{abstract}
ABSTRAK
PT. XYZ merupakan perusahaan dalam bidang industry machining and engineering. Spesialisasi PT. $\mathrm{XYZ}$ adalah dalam manufacturing press parts, dies, jigs, machinery and construction. salah satu produknya yaitu Crank shaft. terdapat sejumlah jenis defect yang melebihi standar toleransi perusahaan. Selama periode Maret hingga Agustus telah ditemukan produk defect sebanyak 1,139 pcs. Six sigma adalah metode yang digunakan untuk pengendalian kualitas, memiliki tujuan untuk menghilangkan cacat produk dan mengurangi biaya. Terdapat lima jenis defect yang ditemukan yakni patah, baret, oversize, longgar, dan aus. Dengan diagram pareto diketahui bahwa ada empat jenis defect crankshaft paling dominan yaitu: baret $29,41 \%$, patah $26.42 \%$ aus $16,06 \%$, dan longgar $14,31 \%$. Dengan menggunakan fishbone diagram dapat disimpulkan bahwa faktor utama dari terjadinya defect adalah bagian mata pisau yang digunakan pada mesin tidak sesuai standar, perawatan mesin kurang maksimal, kurangnya ventilasi udara, dan kualitas bahan baku yang rendah.
\end{abstract}

Kata Kunci: Defect Crankshaft, Six Sigma, DMAIC

\section{PENDAHULUAN}

Pada saat ini perkembangan dunia industri sangat pesat, hal tersebut menuntut banyaknya perusahaan industri untuk mampu bersaing di era global ini. Oleh karna itu tuntutan kualitas dan kuantitas dari suatu produk sangat dibutuhkan. Jika suatu perusahaan dapat memenuhi kualitas dan kuantitas, maka perusahaan tersebut mampu bersaing di dunia industri yang sangat ketat.

Produk-produk PT. XYZ dibuat di bawah kualitas inspeksi dan sistem yang ketat. Pada 23 September 2004, PT. XYZ menerima sertifikasi ISO 9001:2000 (Sertifikat No. 11369) sebagai bukti konsistensi dalam menjaga kualitas produk dan sistemnya

PT. XYZ memproduksi berbagai macam produk di antaranya Crankshaft, Carrier Rear Upper, Clamp Lamp Day Light D21N, Timing Gear, dan lain lain, untuk lebih jelas dapat dilihat di tabel 1 
Murwan widyantoro, Denielson Adisyah

Submitted: 01/11/2020; Revised: 02/11/2020; Accepted: 09/11/2020; Published: 29/12/2020

Tabel 1 Data Produk dan Kerusakan Produk

\begin{tabular}{|c|c|c|c|}
\hline NO & Nama Produk & $\begin{array}{ll}\text { Jenis } & \text { Kerusakan } \\
\text { Produk } & \end{array}$ & $\begin{array}{l}\text { Tingkat } \\
\text { Cacat }\end{array}$ \\
\hline 1 & Crankshaft & Miring, Patah, Pecah & $1,85 \%$ \\
\hline 2 & $\begin{array}{l}\text { Bracket Esparator } \\
\text { Front footstep }\end{array}$ & $\begin{array}{l}\text { Penyok, Lubang baut } \\
\text { longgar }\end{array}$ & $1,62 \%$ \\
\hline 3 & $\begin{array}{l}\text { Bracket Esparator } \\
\text { Rear Footstep }\end{array}$ & $\begin{array}{l}\text { Penyok, Lubang baut } \\
\text { longgar }\end{array}$ & $1,61 \%$ \\
\hline 4 & $\begin{array}{l}\text { Bracket Spacer } \\
\text { Panther }\end{array}$ & Patah, Baret, Oversize & $1,47 \%$ \\
\hline 5 & Timing Gear & Oversize, Patah & $1,31 \%$ \\
\hline 6 & $\begin{array}{l}\text { Muffler } \\
\text { D30N }\end{array}$ & $\begin{array}{lr}\text { Patah, } & \text { Baret, } \\
\text { Oversize, } & \text { Longgar, } \\
\text { Aus } & \end{array}$ & $1,28 \%$ \\
\hline 7 & $\begin{array}{l}\text { Carrier } \\
\text { Upper }\end{array}$ & Penyok, Pecah & $1,21 \%$ \\
\hline 8 & $\begin{array}{l}\text { Carrier } \\
\text { Lower }\end{array}$ & Miring, Patah, Pecah & $1,17 \%$ \\
\hline 9 & $\begin{array}{lr}\text { Plate } & \text { Stand } \\
\text { Triangle } & \end{array}$ & Baret, Patah & $1,11 \%$ \\
\hline 10 & $\begin{array}{l}\text { Bracket Organize } \\
\text { Box Tray MUX }\end{array}$ & Bending terbalik & $1,02 \%$ \\
\hline 11 & $\begin{array}{l}\text { Clamp Lamp Day } \\
\text { Light D21N }\end{array}$ & Bending Miring & $1,01 \%$ \\
\hline
\end{tabular}

Berdasarkan data pada Tabel 1 nilai kecacatan paling tinggi adalah crankshaft dengan total tingkat kecacatan $1,85 \%$, dari permasalahan yang terjadi maka akan dilakukan penelitian untuk mengurangi nilain kecacatan pada crankshaft.

Pada penelitian produk crankshaft dengan metode six sigma untuk memecahkan permasalahan yang ditemukan. Six sigma adalah metode yang digunakan untuk pengendalian kualitas, memiliki tujuan untuk menghilangkan cacat produk dan mengurangi biaya (Haizer et al., 2009). Six sigma juga disebut strategi karena karena terfokus pad peningkatan kepuasan pelanggan, disebut disiplin ilmu karena mengikuti model formal yaitu DMAIC (Define, Measure, Analyze, Improve, Control) (Syukron et al., 2013).

Berdasarkan data nilai kecacatan paling tinggi adalah crankshaft yang baret dengan total kecacatan 335 pcs, dari permasalahan yang terjadi maka akan dilakukan penelitian untuk mengurangi nilain kecacatan pada crankshaft dengan menggunakan metode six sigma.

Untuk lebih jelas dalam melihat jenis kecacatan produk pada produk crankshaft, dapat dilihat pada grafik berkut ini.

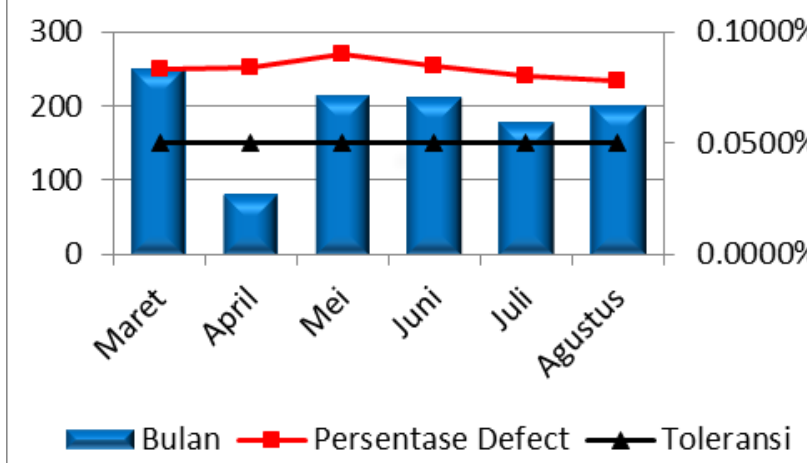

Gambar 1 Diagram persentase produk Defect bulan Maret-Agustus

Pada penelitian produk crankshaft dengan metode six sigma untuk memecahkan permasalahan yang ditemukan. Six sigma adalah metode yang digunakan untuk pengendalian kualitas, memiliki tujuan untuk menghilangkan cacat produk dan mengurangi biaya. Six sigma juga disebut strategi karena karena terfokus pad peningkatan kepuasan pelanggan, disebut disiplin ilmu karena mengikuti model formal yaitu DMAIC (Ahmad, 2019).

\section{METODE PENELITIAN}

Metode penelitian yang digunakan sebagai teknik pengumpulan data dari penelitian ini berupa langkah-langkah yang akan ditempuh dalam memecahkan permasalahan yang hendak dicapai. Teknik pengumpulan data ini merupakan tahapantahapan dan tata cara penulisan laporan penelitian. Fungsinnya adalah sebagai kerangka utama yang menjaga arah tata cara penulisan laporan penelitian untuk mencapai tujuan yang di tetapkan dan meminimalisasi kesalahan yang akan mungkin timbul pada penulisan laporan. Teknik pengumpulan data laporan penelitian ini menggunakan beberapa metode yang meliputi adalah Dari data yang diperoleh, penulis menggunnakan metode DMAIC dan analisanya, sehingga dengan metode tersebut penulis dapat mengetahui faktor terjadinnya penurunan kualiatas perkerja sehingga menyebabkan produk cacat

Setelah data terkumpul dan diidentifikasi maka selanjutnya penulis mengelolah data tersebut sesuia dengan tujuan dan pemecahan masalah. Adapun langkahlangkah dalam pengolahan data adalah sebagai berikut: 
1. Identifikasi masalah bertujuan untuk mengetahui seberapa besar produk yang cacat selama beberapa bulan terakhir. Penulis mengindentifikasi masalah ini ke dalam bentuk check sheet, kemudian di gambarkan dengan memakai diagram paretto

2. Menentukan faktor utama terjadinya produk yang cacat dengan cara menganalisa sebab akibat. Berisi tentang analisa timbulnya suatu akibat, dan mencari faktor-faktor penyebab terjadinya produk yang cacat, penulis menggambarkan diagram dengan menggunakan diagram fishbone

3. Melakukan uji coba perbaikan lingkungan kerja dan langkah-langkah proses pembuatan produk crankshaft yang akan diuji coba. Tujuannya untuk mengetahui apakah masih ada masalah atau tidak didalam proses produksi

4. Memeriksa hasil perbaikan, berisi tentang penulis memeriksa atau mengevaluasi hasil dari perbaikan

5. Standarisasi hasil, setelah memeriksa hasil dari tes uji coba penulis melakukan standarisasi agar tidak terjadi masalah atau produk yang cacat pada saat proses produksi

6. Setelah melakukan standarisasi, penulis melakukan implementasi secara berkesinambungan dan membeikan ususlan kepada perusahaan

Untuk lebih jelasnya, langkah-langkah Define Measure Analyze Improve dan Control (DMAIC) dapat dijabarkan sebagai berikut (Gasperz, 2005), (Naufal et al., 2016), (Siwi et al., 2015):

\section{Define:}

Define merupakan langkah awal didalam pendekatan Six Sigma. Langkah ini mengidentifikasikan masalah penting dalam proses yang berlangsung. Dari masalah tersebut dapat diidentifikasi perlu tidaknya langkah perbaikan.

\section{Measure}

Measure merupakan tindak lanjut dari langkah define dan merupakan sebuah jembatan untuk langkah selanjutnya. Langkah measure memiliki dua sasaran utama, yaitu :

a. Mendapatkan data untuk memvalidasi dan mengkuantifikasi masalah. b. Mulai menyentuh fakta dan angkaangka yang memberikan petunjuk tentang akar masalah.

3. Analyze

Langkah analyze mulai masuk kedalam hal-hal yang bersifat detail, meningkatkan pemahaman terhadap proses dan masalah, serta mengidentifikasi akar masalah. Pengendalian Cacat Produk dengan Pendekatan Six Sigma 38 Untuk memperkirakan kapabilitas proses, maka diperlukan langkah-langkah sebagai berikut (Ekoanindiyo, 2014):

a. Menentukan banyaknya unit yang diperiksa.

b. Menentukan banyaknya unit yang mengalami ketidaksesuaian (cacat).

c. Menghitung tingkat kegagalan $=12$ langkah langkah d. Menentukanbesarnya CTQ potensial yang dapat mengakibatkan kegagalan.

d. Menghitung peluang tingkat kegagalan per karakteristik CTQ = 43 langkah langkah

e. Menghitung kemungkinan gagal per satu juta kesempatan $($ DPMO $=$ Defect Per Million Opportunities). DPMO = X1.000.000 unit diperiksa XCTQ potensial Banyaknya ketidaksesuaian

f. Mengkonversikan DPMO kedalam nilai sigma (menggunakan tabel konversi).

g. Membuat kesimpulan Pada saat mencari jumlah defect digunakan rumus: Jumlah defect $=\mathrm{DPO} \mathrm{X}$ (jumlah unit $\mathrm{X}$ defect opportunity) dimana : DPO (Defect Per Opportunity) $=\mathrm{DPMO} / 1.000 .000$ DPMO (Defect Per Million Opportunities), diperoleh dari tabel konversi nilai DPMO ke dalam sigma.

4. Improve Setelah mengukur dengan cermat dan menganalisa situasinya, maka langkah berikutnya adalah improve, memperbaiki proses atau output guna menyelesaikan masalah. Selama tahap ini, diuraikan ideide perbaikan atau solusi-solusi yang mungkin untuk dilaksanakan (Didiharyono et al., 2018).

5. Control: Control merupakan tahap terakhir dalam peningkatan kualitas Six Sigma. Sebagai bagian dari pendekatan Six Sigma, perlu adanya pengawasan/ 
Murwan widyantoro, Denielson Adisyah

Submitted: 01/11/2020; Revised: 02/11/2020; Accepted: 09/11/2020; Published: 29/12/2020

mengkaji ulang proses untuk meyakinkan bahwa hasil-hasil yang diinginkan sedang dalam proses pencapaian. Hasil dari tahap improve perlu diterapkan untuk melihat pengaruhnya terhadap kualitas produk yang dihasilkan (Susetryo et al., 2011)

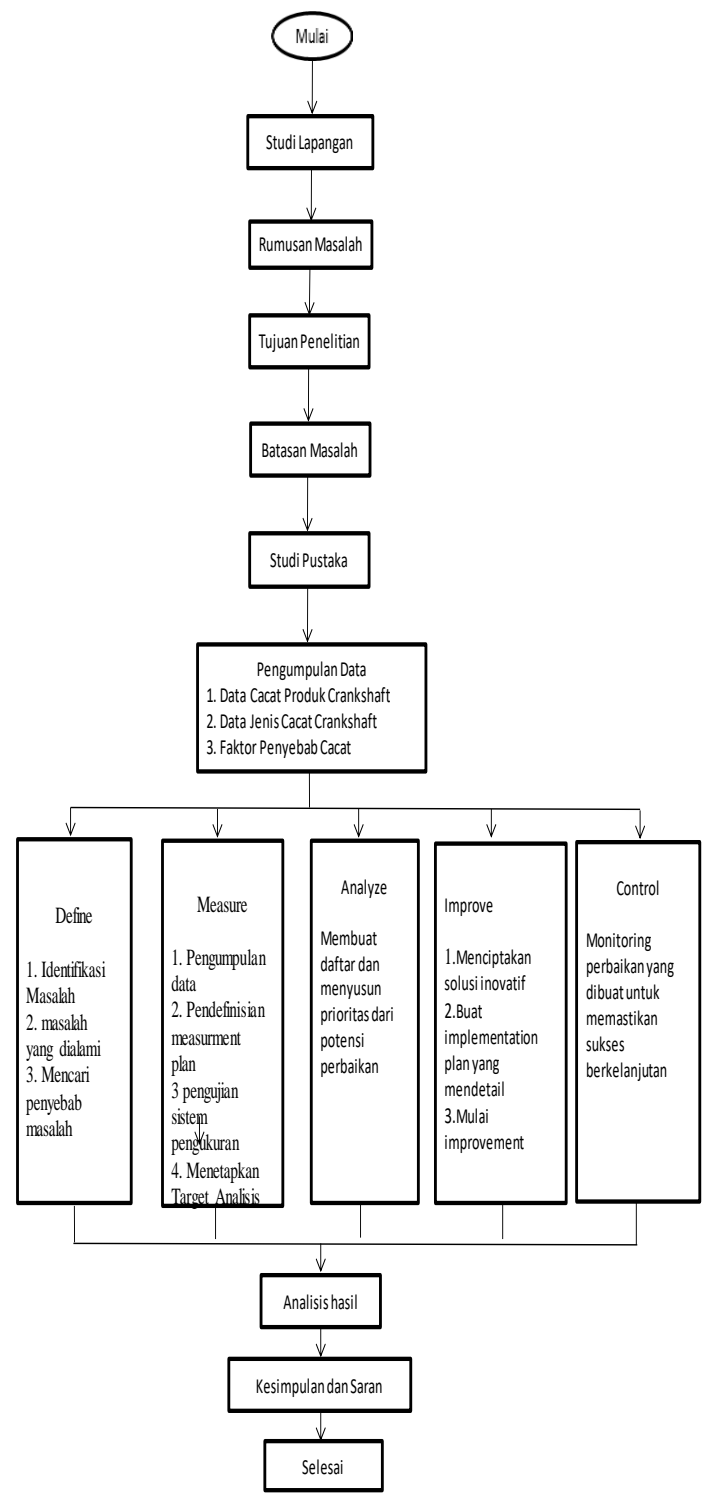

Gambar 2 Kerangka berpikir

\section{HASIL DAN PEMBAHASAN}

Pengukuran Nilai Sigma

1. Menghitung DPO (Defect Per Opportunities)

$\mathrm{DPO}=\frac{\text { Total Defect }}{\text { Total Produksix CTQ }}$

Bulan Maret

$$
\mathrm{DPO}=\frac{251}{10000 \mathrm{x} 5}=0,005020
$$

2. Menghitung DPMO (Defect Per Million Opportunites)

$$
\mathrm{DPMO}=\frac{\text { Total Defect }}{\text { Total Produlssix CTQ }} \times 1.000 .000
$$

Bulan Maret

$$
\mathrm{DPMO}=\frac{251}{10000 \times 5} x 1.000 .000=5020
$$

Konversi dilakukan dengan menggunakan aplikasi Microsoft Excel dengan formula:

$$
\text { Nilai Sigma=Normsinv }\left(\frac{1 \text {-DPNO }}{1,000000}\right) \mathrm{X}_{z}, 5
$$

Tabel 2 Hasil pengukuran nilai sigma

\begin{tabular}{crrr}
\hline Bulan & DPO & DPMO & $\begin{array}{c}\text { Nilai } \\
\text { Sigma }\end{array}$ \\
\hline Maret & 0,00502 & 5020 & 4,07 \\
\hline April & 0,00162 & 1620 & 4,44 \\
\hline Mei & 0,004095 & 4095,238 & 4,13 \\
\hline Juni & 0,004988 & 4988,235 & 4,13 \\
\hline Juli & 0,003096 & 3095,652 & 4,19 \\
Agustus & 0,003673 & 3672,727 & 4,15 \\
\hline Rata-rata & 0,003749 & 3749 & 4,19 \\
\hline
\end{tabular}

Berdasarkan tabel 2 hasil pengukuran nilai sigma, dari bulan Maret 2019 hingga Agustus 2019 proses produksi crankshaft PT. XYZ memiliki rata-rata nilai sigma 4,19 . Langkah selanjutnya adalah menentukan prioritas perbaikan menggunakan diagram Pareto. 
Murwan widyantoro, Denielson Adisyah

Submitted: 01/11/2020; Revised: 02/11/2020; Accepted: 09/11/2020; Published: 29/12/2020

Tabel 3 Data Defect Crankshaft

\begin{tabular}{|c|c|c|c|c|c|c|}
\hline \multirow{2}{*}{ Bulan } & \multicolumn{5}{|c|}{ Defect } & \multirow[t]{2}{*}{$\begin{array}{c}\text { Jumla } \\
\mathrm{h}\end{array}$} \\
\hline & $\begin{array}{c}\text { Pata } \\
\mathrm{h}\end{array}$ & $\begin{array}{c}\text { Bare } \\
\mathrm{t}\end{array}$ & $\begin{array}{c}\text { Oversiz } \\
\mathrm{e}\end{array}$ & $\begin{array}{c}\text { Longga } \\
\mathrm{r}\end{array}$ & $\begin{array}{c}\mathrm{Hau} \\
\mathrm{s} \\
\end{array}$ & \\
\hline Maret & 76 & 85 & 41 & 27 & 22 & 251 \\
\hline April & 12 & 21 & 17 & 16 & 15 & 81 \\
\hline Mei & 58 & 44 & 31 & 39 & 43 & 215 \\
\hline Juni & 66 & 61 & 18 & 28 & 39 & 212 \\
\hline Juli & 41 & 49 & 27 & 21 & 40 & 178 \\
\hline $\begin{array}{c}\text { Agustu } \\
\text { S }\end{array}$ & 48 & 75 & 23 & 32 & 24 & 202 \\
\hline Jumlah & 301 & 335 & 157 & 163 & 183 & 1139 \\
\hline
\end{tabular}

Diagram pareto produksi crankshaft

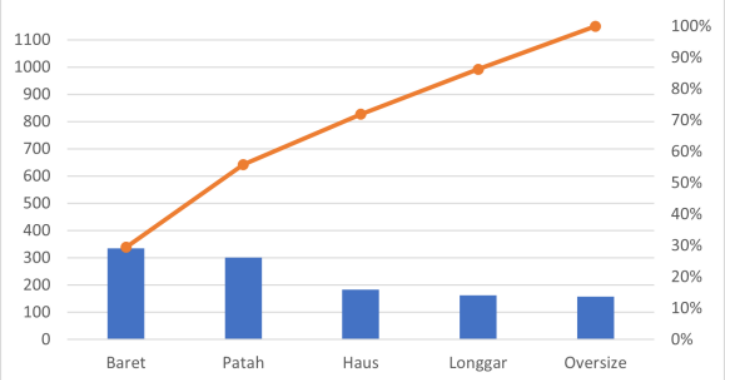

Gambar 3 Diagram pareto produksi crankshaft

\section{Tahap Analyze}

Hasil dari tahap measure dapat diketahui $C T Q$ yang paling dominan adalah Baret, Patah, Longgar, dan Aus. Lalu selanjutnya akan dievaluasi untuk mengetahui penyebab jenis defect yang sering terjadi dijelaskan di diagram sebab akibat yang merupakan suatu penjelasan analisa dalam menemukan penyebab suatu masalah yang ada.

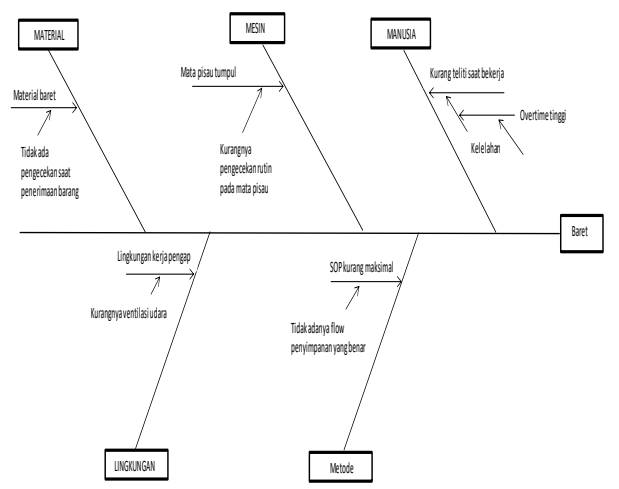

Gambar 4 Diagram sebab akibat defect baret

Melalui diagram sebab akibat pada gambar 4 dijelaskan bahwa penyebab terjadinya defect baret disebabkan oleh lima hal diantaranya yaitu manusia, mesin, material, lingkungan dan metode. Dari penyebab defect ada masing-masing faktor penyebabnya, yaitu diantaranya:

1. Faktor Manusia

Penyetingan mesin tidak pas, faktor ini dikarenakan tidak ada bimbingan pada saat mengoprasikan mesin yang mengakibatkan setiap pekerjaan yang dilakukan menjadi kurang maksimal. Sehingga perlu adanya bimbingan untuk meminimalisasi terjadinya defect pada produk.

2. Faktor Mesin

a. Posisi mata pisau tidak presisi, biasanya dikarenakan kurangnya pengawasan dari departemen mauintenance dan kurang pedulinya operator terhadap mesin tersebut.

b. Mata pisau tumpul, kurang pedulinya operator terhadap mesin dan SOP yang ada tidak terlaksanakan.

3. Faktor Material

Bahan material Baret, terjadi karena tidak adanya penegcekan saat penerimaan barang.

4. Faktor Lingkungan

a. Ruangan kerja pengap, faktor ini bisa menyebabkan operator kurang nyaman dengan kondisi ruangan yang pengap sehingga konsentrasipun berkurang.

b. Ventilasi udara yang kurang banyak, kondisi ini sangat berpengaruh terhadap kinerja operator karena dapat mengurangi konsentrasi dalam bekerja.

5. Faktor Metode

SOP kurang maksimal, dikarenakan tidak adanya flow penyimpanan yang benar

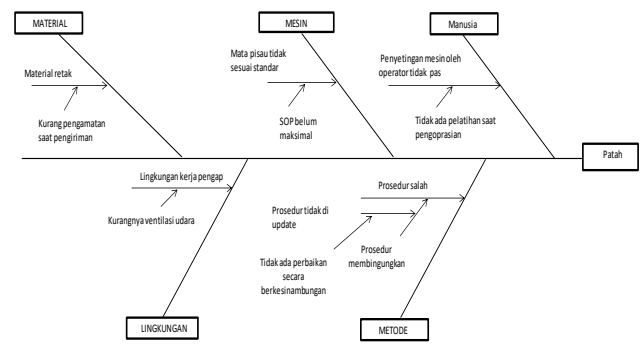

Gambar 5 Diagram sebab akibat defect patah

Pada Gambar 5 adalah diagram sebab akibat dari defect patah, terdapat lima faktor 
yaitu dari faktor manusia, mesin, material, lingkungan dan metode. Berikut adalah penjelasannya:

1. Faktor Manusia

Penyetingan tidak pas, karena tidak adanya pelatihan saat pengoprasian mesin yang membuat karyawan jadi tidak disiplin.

2. Faktor Mesin

Mata pisau yang tidak sesuai standar, operator mesin yang belum mengusai pengaturan yang tepat maka membuat mata pisau tidak sesuai dengan standar.

3. Faktor Material

Material retak, kurang pengamatan pada saat pengiriman material sebaiknya diperiksa lagi untuk mencegah terjadinya material retak.

4. Faktor Lingkungan

a. Ruang kerja pengap, faktor ini bisa menyebabkan operator kurang nyaman dengan kondisi ruangan yang pengap sehingga konsentrasi pun berkurang.

b. Ventilasi udara yang kurang banyak, kondisi ini sangat berpengaruh terhadap kinerja operator karena dapat mengurangi konsentrasi dalam bekerja.

5. Faktor Metode

SOP kurang maksimal,dikarenakan tidak ada perbaikan secara berkesinambungan.

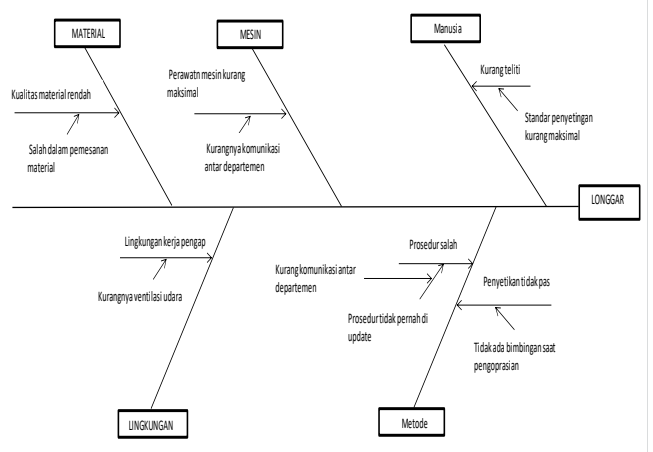

Gambar 6 Diagram sebab akibat defect longgar
Pada Gambar 6 adalah diagram sebab akibat dari defect patah, terdapat lima faktor yaitu dari faktor manusia, mesin, material, lingkungan dan metode. Berikut adalah penjelasannya:

1. Faktor Manusia

Penyetingan tidak pas, karena tidak adanya pelatihan saat pengoprasian mesin yang membuat karyawan jadi tidak disiplin.

2. Faktor Mesin

Mata pisau yang tidak sesuai standar, operator mesin yang belum mengusai pengaturan yang tepat maka membuat mata pisau tidak sesuai dengan standar.

3. Faktor Material

Material retak, kurang pengamatan pada saat pengiriman material sebaiknya diperiksa lagi untuk mencegah terjadinya material retak.

4. Faktor Lingkungan

a. Ruang kerja pengap, faktor ini bisa menyebabkan operator kurang nyaman dengan kondisi ruangan yang pengap sehingga konsentrasi pun berkurang.

b. Ventilasi udara yang kurang banyak, kondisi ini sangat berpengaruh terhadap kinerja operator karena dapat mengurangi konsentrasi dalam bekerja.

5. Faktor Metode

SOP kurang maksimal,dikarenakan tidak ada perbaikan secara berkesinambungan.

Untuk mengetahui faktor mana yang paling berpengaruh terhadap akar permasalahan dari kejadian defect, maka diadakan wawancara terhadap beberapa operator melalui kuisioner dengan skala penilaian 1-10. Hasil kuisionernya dapat dilihat pada Tabel 4, 5, 6, dan 7 
Tabel 4 Hasil Kuisioner Defect Baret

Keryawan

\begin{tabular}{|c|c|c|c|c|c|c|c|c|}
\hline Faktor & $\begin{array}{c}\text { Akar } \\
\text { Permasalahan }\end{array}$ & Leader & $\begin{array}{c}\text { Operator } \\
1\end{array}$ & $\begin{array}{c}\text { Operator } \\
2\end{array}$ & $\begin{array}{c}\text { Operator } \\
3\end{array}$ & $\begin{array}{c}\text { Operator } \\
4\end{array}$ & $\begin{array}{c}\text { Operator } \\
5\end{array}$ & Total \\
\hline & Material & & & & & & & \\
\hline Material & $\begin{array}{l}\text { Baret } \\
\text { Mata nisau }\end{array}$ & 5 & 2 & 2 & 3 & 1 & 3 & 16 \\
\hline Mesin & $\begin{array}{l}\text { tumpul } \\
\text { Lingkungan }\end{array}$ & 3 & 3 & 2 & 2 & 4 & 2 & 16 \\
\hline Lingkungan & $\begin{array}{l}\text { kerja pengap } \\
\text { SOP kurang }\end{array}$ & 5 & 6 & 4 & 5 & 6 & 7 & 33 \\
\hline Metode & $\begin{array}{l}\text { maksimal } \\
\text { Kurang teliti }\end{array}$ & 3 & 3 & 4 & 3 & 2 & 4 & 19 \\
\hline Manusia & saat bekerja & 8 & 7 & 6 & 9 & 8 & 7 & 45 \\
\hline Manusia & $\begin{array}{l}\text { Kelelahan } \\
\text { Overtime }\end{array}$ & 5 & 6 & 5 & 7 & 7 & 4 & 34 \\
\hline Manusia & Tinggi & 5 & 6 & 5 & 3 & 4 & 4 & 27 \\
\hline
\end{tabular}

Tabel 5 Hasil Kuisioner Defect Patah

Keryawan

\begin{tabular}{|c|c|c|c|c|c|c|c|c|}
\hline Faktor & $\begin{array}{c}\text { Akar } \\
\text { Permasalahan }\end{array}$ & $\begin{array}{l}\text { Leade } \\
\mathrm{r}\end{array}$ & $\begin{array}{l}\text { Operato } \\
\text { r } 1\end{array}$ & $\begin{array}{l}\text { Operato } \\
\text { r } 2\end{array}$ & $\begin{array}{l}\text { Operato } \\
\text { r } 3\end{array}$ & $\begin{array}{l}\text { Operato } \\
\text { r } 4\end{array}$ & $\begin{array}{l}\text { Operato } \\
\text { r } 5\end{array}$ & $\begin{array}{c}\text { Tota } \\
1\end{array}$ \\
\hline Material & $\begin{array}{l}\text { Material retak } \\
\text { Mata pisau } \\
\text { tidak sesuai }\end{array}$ & 5 & 2 & 2 & 3 & 1 & 3 & 16 \\
\hline Mesin & standar & 3 & 3 & 2 & 2 & 4 & 2 & 16 \\
\hline Manusia & $\begin{array}{l}\text { Setting mesin } \\
\text { oleh operator } \\
\text { tidak pas }\end{array}$ & 5 & 2 & 4 & 5 & 1 & 3 & 20 \\
\hline $\begin{array}{l}\text { Lingkunga } \\
\mathrm{n}\end{array}$ & $\begin{array}{l}\text { Lingkungan } \\
\text { kerja pengap }\end{array}$ & 3 & 3 & 4 & 3 & 2 & 4 & 19 \\
\hline Metode & $\begin{array}{l}\text { Prosedur salah } \\
\text { Prosedur } \\
\text { Membingungka }\end{array}$ & 3 & 7 & 6 & 5 & 8 & 5 & 34 \\
\hline Metode & $\mathrm{n}$ & 5 & 6 & 5 & 7 & 7 & 9 & 39 \\
\hline Metode & $\begin{array}{l}\text { Prosedur tidak } \\
\text { update }\end{array}$ & 5 & 6 & 5 & 3 & 4 & 4 & 27 \\
\hline
\end{tabular}


Tabel 6 Hasil Kuisioner Defect Longgar

\section{Keryawan}

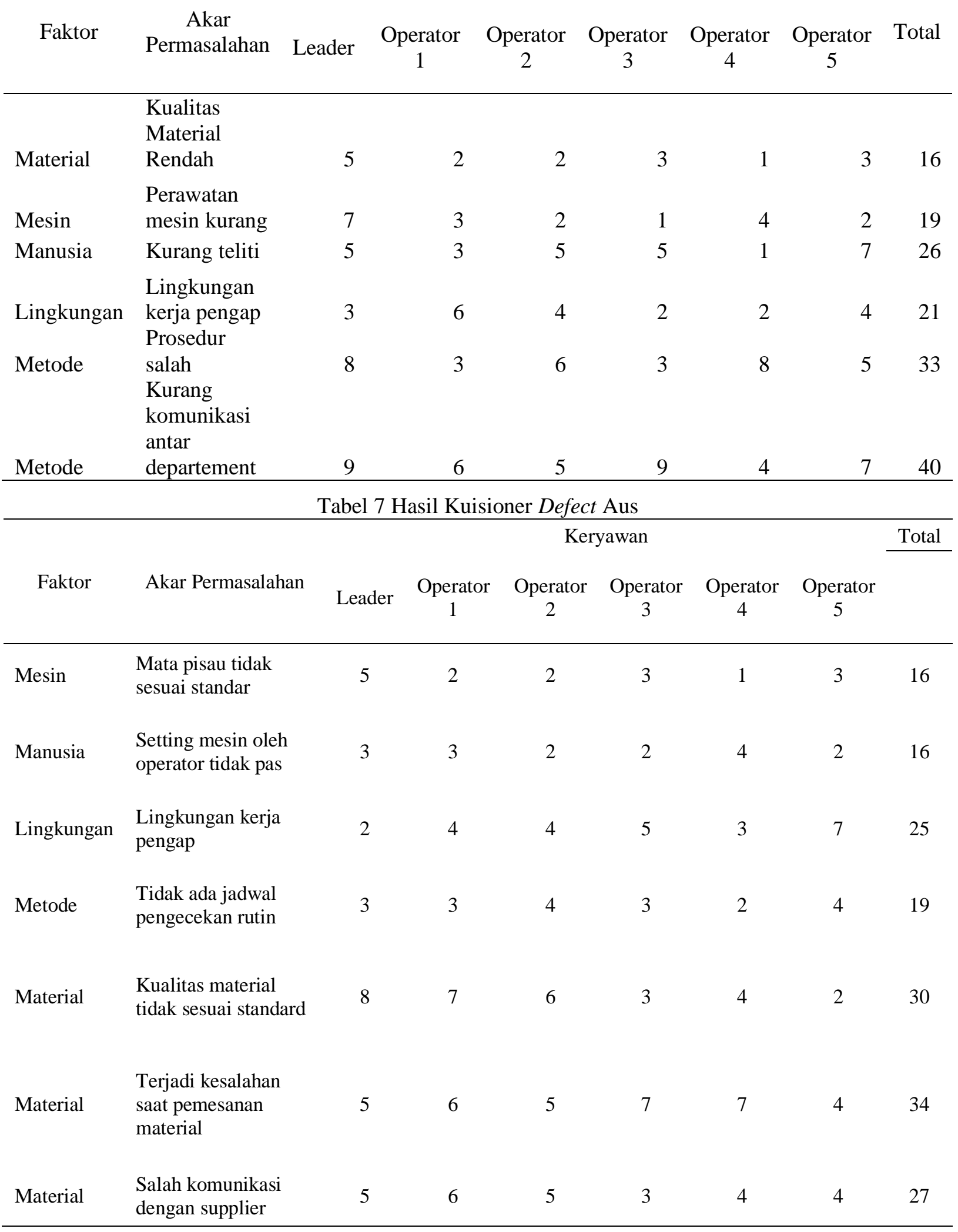


Murwan widyantoro, Denielson Adisyah

Submitted: 01/11/2020; Revised: 02/11/2020; Accepted: 09/11/2020; Published: 29/12/2020

Seperti terlihat pada tabel 4 terlihat bahwa untuk defect baret, faktor paling berpengaruh adalah faktor manusia dengan akar permasalahannya yaitu kurang teliti saat bekerja. Pada tabel 5 terlihat bahwa untuk defect patah, faktor yang paling berpengaruh adalah faktor metode dengan akar permasalahan prosedur membingungkan. Sedangkan pada tabel 6 terlihat bahwa untuk defect longgar, faktor paling dominan adalah faktor metode dengan akar permasalahan kurang komunikasi antar departemen. Dan pada tabel 7 terlihat bahwa untuk defect aus, faktor paling dominan adalah faktor material dengan akar permasalahan terjadi kesalahan saat pemesanan material

\section{Tahap Improve}

Improve merupakan tahapan perbaikan terhadap sumber-sumber yang meyebabkan defect produk berdasarkan hasil analisis diagram sebab akibat dan prioritas perbaikan berdasarakan masalah defect yang ada. Berdasarkan data yang telah didapat pada jenis defect yang tingkat kegagalannya tinggi dan defect ini sangatlah berpengaruh besar dalam penurunan kualitas yang berada di luar batas toleransi perusahaan.

Hal ini menandakan bahwa proses pembuatan crankshaft terdapat penurunan kualitas yang harus dilakukan perbaikan dengan menggunakan metode $5 \mathrm{~W}+1 \mathrm{H}$ (What $=$ tujuan utama, Why = alasan, Where = lokasi, When =kapan, Who = orang dan How = metode) dengan bertujuan untuk meningkatkan kualitas dan tindakan (Tannady, 2015).
Tabel 8 Tahap Improve untuk jenis defect baret pada produk cranksahft

\begin{tabular}{|c|c|c|}
\hline Jenis & $5 \mathrm{~W}+1 \mathrm{H}$ & $\begin{array}{l}\text { Deskripsi Tindakan } \\
\text { (Manusia) }\end{array}$ \\
\hline $\begin{array}{l}\text { Tujuan } \\
\text { Utama }\end{array}$ & What (Apa) & $\begin{array}{l}\text { Kurang teliti saat } \\
\text { bekerja }\end{array}$ \\
\hline Alasan & $\begin{array}{c}\text { Why } \\
\text { (Mengapa) }\end{array}$ & $\begin{array}{c}\text { Mengobrol saat } \\
\text { bekerja serta tidak } \\
\text { ada arahan SOP yang } \\
\text { benar }\end{array}$ \\
\hline Orang & Who (Siapa) & Operator \\
\hline Tempat & $\begin{array}{l}\text { Where } \\
\text { (Dimana) }\end{array}$ & Line produksi \\
\hline Waktu & $\begin{array}{l}\text { When } \\
\text { (Kapan) }\end{array}$ & Maret-Juni 2019 \\
\hline Metode & $\begin{array}{c}\text { How } \\
\text { (Bagaimana) }\end{array}$ & $\begin{array}{l}\text { Diadakan briefing } \\
\text { agar mengikuti } \\
\text { arahan SOP disetiap } \\
\text { awal kerja dan } \\
\text { pelatihan } \\
\text { peningkatan skill } \\
\text { pada operator } \\
\end{array}$ \\
\hline \multicolumn{3}{|c|}{$\begin{array}{c}\text { Tabel } 9 \text { Tahap Improve untuk jenis defect } \\
\text { patah pada produk cranksahft }\end{array}$} \\
\hline Jenis & $5 \mathrm{~W}+1 \mathrm{H}$ & $\begin{array}{l}\text { Deskripsi } \\
\text { Tindakan } \\
\text { (Manusia) }\end{array}$ \\
\hline $\begin{array}{l}\text { Tujuan } \\
\text { Utama }\end{array}$ & What (Apa) & $\begin{array}{c}\text { Prosedur } \\
\text { membingungkan }\end{array}$ \\
\hline Alasan & $\begin{array}{c}\text { Why } \\
\text { (Mengapa) }\end{array}$ & $\begin{array}{l}\text { Prosedur tidak } \\
\text { pernah di update }\end{array}$ \\
\hline Orang & Who (Siapa) & Operator \\
\hline Tempat & $\begin{array}{l}\text { Where } \\
\text { (Dimana) }\end{array}$ & Line produksi \\
\hline Waktu & When (Kapan) & April-mei 2019 \\
\hline Metode & $\begin{array}{c}\text { How } \\
\text { (Bagaimana) }\end{array}$ & $\begin{array}{c}\text { Diadakan } \\
\text { pembaruan } \\
\text { prosedur secara } \\
\text { rutin untuk } \\
\text { mengurangi defect } \\
\text { pada produksi } \\
\text { crankshaft }\end{array}$ \\
\hline
\end{tabular}


Murwan widyantoro, Denielson Adisyah

Submitted: 01/11/2020; Revised: 02/11/2020; Accepted: 09/11/2020; Published: 29/12/2020

Tabel 10 Tahap Improve untuk jenis defect aus pada produk cranksahft

\begin{tabular}{|c|c|c|}
\hline Jenis & $5 \mathrm{~W}+1 \mathrm{H}$ & $\begin{array}{l}\text { Deskripsi } \\
\text { Tindakan } \\
\text { (Manusia) }\end{array}$ \\
\hline $\begin{array}{l}\text { Tujuan } \\
\text { Utama }\end{array}$ & What (Apa) & $\begin{array}{l}\text { Terjadi kesalahan } \\
\text { saat pemesanan } \\
\text { material }\end{array}$ \\
\hline Alasan & $\begin{array}{c}\text { Why } \\
\text { (Mengapa) }\end{array}$ & $\begin{array}{l}\text { Salah komunikasi } \\
\text { dengan supplier }\end{array}$ \\
\hline Orang & Who (Siapa) & Leader \\
\hline Tempat & $\begin{array}{c}\text { Where } \\
\text { (Dimana) }\end{array}$ & Line produksi \\
\hline Waktu & When (Kapan) & Juli-Agustus 2019 \\
\hline Metode & $\begin{array}{c}\text { How } \\
\text { (Bagaimana) }\end{array}$ & $\begin{array}{c}\text { Melakukan } \\
\text { komunikasi secara } \\
\text { mendalam dengan } \\
\text { supplier agar tidak } \\
\text { terjadi salah } \\
\text { komunikasi pada } \\
\text { saat pemesanan } \\
\text { material }\end{array}$ \\
\hline
\end{tabular}

\section{KESIMPULAN DAN SARAN KESIMPULAN}

Berdasarkan hasil pengolahan data dan analisa, yang telah yang telah dilakukan dengan menggunakan metode DMAIC, maka dapat dibuat kesimpulan antara lain yaitu: terdapat lima jenis defect yang ditemukan pada proses produksi crankshaft di PT. XYZ yakni baret, patah, oversize, longgar, dan aus, berdasarkan perhitungan nilai Sigma, rata-rata nilai sigma perusahaan adalah 4,19 dengan 3749 Defect Per Million Opportunities (DPMO), setelah menggunakan diagram pareto dapat diketahui bahwa ada empat jenis defect crankshaft paling dominan yaitu: baret sebanyak $29,41 \%$, patah sebanyak $26.42 \%$ aus sebanyak 16,06\%, dan longgar sebanyak $14,31 \%$, dengan menggunakan dapat ditarik kesimpulan bahwa akar masalah dari terjadinya defect adalah bagian mata pisau yang digunakan pada mesin tidak sesuai standar, perawatan mesin kurang maksimal, kurangnya ventilasi udara, dan kualitas bahan baku yang rendah

\section{SARAN}

Dari hasil pembahasan dan kesimpulan penelitian, dapat dikemukakan beberapa saran yang dapat dipertimbangkan oleh perusahaan sebagai berikut:

1. Mengadakan briefing di setiap awal waktu kerja oleh leader atau supervisor yang ada di PT. XYZ.

2. Melakukan maintenance harian yang lebih menyeluruh pada seluruh area produksi.

3. Melakukan pengawasan yang lebih baik terhadap bahan baku yang diterima dari suppliers.

4. Menambahkan ventilasi udara.

\section{DAFTAR PUSTAKA}

Ahmad, F. (2019). Six Sigma Dmaic Sebagai Metode Pengendalian Kualitas Produk

Kursi Pada Ukm. Jurnal Integrasi Sistem Industri, 6(1), 11-17.

Didiharyono, Marsal, \& Bakhtiar. (2018). Analisis Pengendalian Kualitas Produksi Dengan Metode Six- Sigma Pada Industri Air Minum PT Asera Tirta Posidonia , Kota Palopo Quality Control Analysis of Production with Six-Sigma Method in. Jurnal Sainsmat, VII(2), 163-176.

Ekoanindiyo, F. A. (2014). Pengendalian Cacat Produk Dengan Pendekatan Six Sigma. Jurnal Dinamika Teknik, 8(1), 35-43.

Gasperz, V. (2005). Total Quality Management. Jakarta: PT. Gramedia Pustaka Utama

Haizer, J. \& Render, B. (2009). Manajemen Operasi Edisi Sembilan. Jakarta: Salemba Empat.

Naufal, I., \& Arvianto, A. (2016). Aplikasi Six Sigma Dmaic Sebagai Metode Pengendalian Dan Perbaikan Kualitas Produk Bedside Cabinet Skn 04-03Abs Pada PT. Sarandi Karya Nugraha. Industrial Engineering Online Journal, 5(4), 78-87.

Siwi, B. R., \& St, S. N. W. P. (2016). Pengendalian Dan Perbaikan Kualitas Produk Pt . Sarandi Karya Nugraha. Industrial Engineering Online Journal, 
Murwan widyantoro, Denielson Adisyah

Submitted: 01/11/2020; Revised: 02/11/2020; Accepted: 09/11/2020; Published: 29/12/2020

$5(4), 1-8$.

Susetryo, J., Winarni, \& Hartanto, C. (2011). Aplikasi Six Sigma DMAIC dan Kaizen sebagai Metode Pengendalian dan Perbaikan Kualitas Produk. Jurnal Teknologi, 4(1), 61-53. https://doi.org/10.22214/ijraset.2020.310

\section{1}

Syukron, A. Kholil, M. (2013). Six Sigma: quality for business improvement. Yogyakarta: Graha Ilmu.

Tannady, H. (2015). Pengendalian Kualitas. Yogyakarta: Graha Ilmu 